\title{
Perspective in predicting the effect of pleurodesis in the treatment of malignant pleural effusions
}

\author{
Habal $\mathrm{P}^{1}$, Omran $\mathrm{N}^{1}$, Kovacicova $\mathrm{K}^{3}$, Chek $\mathrm{J}^{1}$, Jankovicova $\mathrm{K}^{2}$, Mandak $\mathrm{J}^{1}$ \\ Department of Cardiac Surgery, Charles University in Prague, Faculty of Medicine in Hradec Kralove \\ and University Hospital in Hradec Kralove, Czech Republic. phabal@seznam.cz
}

\begin{abstract}
Background: Pleurodesis with talc has been used for many years. No objective criteria of inflammatory symptoms are known in order to use them to predict the effect of therapy and selection of patients. Purpose of the study: To objectify the course of local inflammatory changes in the pleural cavity, quantify their dynamics in a clinically used procedure, and to determine specific predictors of inflammation as perspective markers of selection of patients suitable for talcage.

Material and method: A total of 114 patients were retrospectively divided into Group $A\left(n_{1}=98\right)$ of patients without relapse and Group $B\left(n_{2}=16\right)$ of patients with relapse of exudate. The need for repeated thoracic punctures or drainages over the course of a 12-month monitoring period was the criterion of treatment failure.

Results: The groups were not different as for the baseline values of sTLR-2 $\left(p_{0}=0.638\right)$. Group A showed a marked growth during the monitoring period in 2 hours following talcage $\left(p_{2}=0.002\right)$ and in 24 hours $\left(p_{24}=0.016\right)$. Group B showed higher SCD-163 levels $\left(p_{0}<0.001\right)$. The initial STREM-1 values and those after two hours were similar in both groups $\left(p_{0}=0.146 ; p_{2}<0.0641\right)$. In 24 hours, Group A had markedly higher values $\left(p_{24}<0.001\right)$. Conclusion: The sTLR-2, SCD-163 and STREM-1 values can be prospectively determined. High SCD-163 values predict unsuitable selection of a candidate for talcage. The degree of inflammatory response can be evaluated using STLR-2 or STREM-1. Talcage using an inserted thoracic drain can be repeated at low levels. The cost of ELISA examination is approximately 18 euros (Tab. 1, Fig. 4, Ref. 20). Text in PDF www.elis.sk. Key words: malign pleural exudate, thoracoscopy, talc, sCD163, sTLR2, sTREM1.
\end{abstract}

\section{Introduction}

Malign pleural exudate is formed in a pathologically modified space between the sheets of the parietal and visceral pleurae. Under physiologic conditions there is a virtual space between the sheets of parietal and visceral pleurae of 10-20 $\mu \mathrm{m}$ in width (1). Overproduction is caused either by imbalance of transpleural pressures or by increased permeability of capillary endothelium with impairment of lymphatic drainage (2). Its worldwide annual incidence is $0.06 \%$ (3). The type of exudate can be specified in relation to the diagnosis of the underlying malign disease (4). The only one effective palliative therapy used so far is the administration of talc using the thoracoscopic (VTS) method (5). The principle of pleurodesis consists in eliminating the interpleural space by inducing aseptic pleuritis. The efficacy of administration of powder form of talc is $90 \%(6)$.

Overall inflammatory responses of the body to administration of a foreign substance are only occasionally evaluated (7). Informa-

${ }^{1}$ Department of Cardiac Surgery, Charles University in Prague, Faculty of Medicine in Hradec Kralove and University Hospital in Hradec Kralove, Czech Republic, ${ }^{2}$ Institute of Clinical Immunology and Allergology, Charles University in Prague, Faculty of Medicine in Hradec Kralove and University Hospital in Hradec Kralove, Czech Republic, and ${ }^{3}$ Department of Surgery The Merciful Brothers Hospital in Brno, Czech Republic

Acknowledgement: Supported by the programme PRVOUK P37/4 and the MH CZ-DRO (UHHK, 00179906. tion and objective evaluation of early local response to administration of a foreign substance is missing (8). External stimuli induce signals of danger for the body and they can be identified by means of toll-like receptors (TLR). Therefore, the group of TLR receptors has a strong anti-inflammatory significance in regulation of inflammatory response.

The binding of foreign substance to the receptor triggers a cascade of cytokine production which activates $\mathrm{T}$ and $\mathrm{B}$ lymphocytes (9).

Soluble CD-163 is a scavenger receptor for haemoglobin. It is present mainly on monocytes and macrophages. It has an antiinflammatory effect while the dynamics of its changes may be used as an indicator of inflammatory response (10).

The soluble receptor called TREM-1, a regulator of innate immunity, is produced by myeloid cells (11). It enhances the inflammatory response to infectious stimuli.

The purpose of the study was to determine specific predictors of inflammation in the clinically used therapeutic procedure as prospective markers of selection of suitable patients with VTS talcage.

\section{Material and method}

The group included 114 patients with a repeated development of malign pleural exudate. Quantification of the volume of exudate was performed with the ultrasound (USG) device - Toshiba Xario ${ }^{\circledR}$ (Toshiba Medical Systems, Sweden) using the convex 
Tab. 1. Basic diagnoses $(n=114)$.

\begin{tabular}{|c|c|c|c|}
\hline & Group A* & Group B* & $\mathrm{p}$ value \\
\hline Age (year) & $63.6 \pm 3.2$ & $67.8 \pm 2.4$ & $<0.05$ \\
\hline BMI (kg.m $\left.{ }^{-2}\right)$ & $27(23-29)$ & $26(24-30)$ & n.s. \\
\hline Thoracoscore** & $5.4(2.7-8.2)$ & $6.9(5.2-7.9)$ & $<0.05$ \\
\hline Volume of exsudate $(\mathrm{ml})$ & $1000 \pm 200$ & $1500 \pm 300$ & $<0.05$ \\
\hline Carcinoma of lungs $n(\%)$ & $29(29.6 \%)$ & $2(14.3 \%)$ & $<0.001$ \\
\hline Malignant mesothelioma n (\%) & $25(25.6 \%)$ & $8(50 \%)$ & $<0.001$ \\
\hline Malignant thymoma n (\%) & $5(5.1 \%)$ & 0 & $<0.001$ \\
\hline Metastases n (\%) & $39(39.8 \%)$ & $6(42.8 \%)$ & $<0.001$ \\
\hline - breast n $(\%)$ & $-19(48 \%)$ & $-2(33.3 \%)$ & $<0.001$ \\
\hline - ovary n (\%) & $-12(30.8 \%)$ & 0 & $<0.001$ \\
\hline - GIT n $(\%)$ & $-4(10.3 \%)$ & 0 & $<0.001$ \\
\hline - lymphoma n (\%) & $-2(5.1 \%)$ & 0 & $<0.001$ \\
\hline - grawitz n (\%) & $-2(5.1 \%)$ & 0 & $<0.001$ \\
\hline$\Sigma \mathrm{n}(\%)$ & $98(86 \%)$ & $16(14 \%)$ & $<0.001$ \\
\hline
\end{tabular}

BMI - Body mass index, * - median (minimum - maximum), A - group without exudate relapsing, B - group with exudate relapsing, ${ }^{*} *$ - Falcoz, P. E., Massim et al. The Thoracic Surgery Scoring System (Thoracoscore): Risk model for in hospital death in 15183 patients requiring thoracic surgery ( $\mathrm{J}$ Thorac Cardiovasc Surg, 2007; 133: 325-332)

probe 2-5 MHz. Following evaluation of efficacy, the group was retrospectively divided into Group A $\left(\mathrm{n}_{1}=98\right)$ of patients without relapse and Group B $\left(n_{2}=16\right)$ of patients with relapse of exudate.

Exudate was evacuated in fractions perioperatively under general anaesthesia. Observation of the pleural cavity was followed by biopsy of the parietal pleura and administration of $5 \mathrm{~g}$ of talc. The thoracic drain was removed with a drained amount $<$ $150 \mathrm{ml} / 24$ hours.

A volume of $5 \mathrm{ml}$ of the pleural effusion was collected in a test tube with heparin by means of a BD Vacutainer ${ }^{\circledR}$ (BD (Becton, Dickinson and Company, USA) with commercially ensured defined heparinization.

The sample was centrifuged, flow cytometry and enzymatic imunoalanalysis was used to determine the fractions of leukocyte subpopulations and sTREM, sCD163, sTLR.

\section{Statistical analysis}

Flow cytometry data were analysed by software (Tree Star, USA). Clinical data, flow cytometry results and ELISA results were statistically analysed by MedCalc statistical software. Comparison between pleural effusion collection in three intervals was assessedby paired t-tests or by Wilcoxon test according to the normality of the data. Differences between groups were tested by t-tests or Mann-Whitney test according to the normality of the data. Categorical data were tested by the Fisher exact test. Statistical significance was set at $\mathrm{p}=0.05$.

The study protocol was approved by the Ethics Committee of the University Hospital in Hradec Kralove and an informed consent was obtained from all participants.

\section{Results}

The group included 114 patients with malign pleural exudate of various origin, $61(53.5 \%)$ males and $53(46.5 \%)$ females. Of them $98(86 \%)$ of patients (Group A) had no relapse. Treatment failure occurred in 16 (14\%) of patients (Group B). The patient age range was $63.6 \pm 3.2$ years in Group A and $67.8 \pm 2.4$ years in Group B. Demographic data are included in Table 1. The mean duration of surgery was $44 \pm 12$ minutes; the mean time of chest drainage was $5 \pm 2$ days. Duration of hospitalization was $7 \pm 2$ days.

Both groups had different volume of exudate at admission ${ }_{\text {(Ad) }}$ $\left(\mathrm{p}_{\mathrm{Ad}}=0.0014\right)$. There were no statistically significant differences in residual volume of exudate at discharge ${ }_{(D)}\left(p_{D}=0.121\right)$. From the first month and for the entire duration of monitoring, significant differences in volume were found between groups A and B $\left(\mathrm{p}_{1-12}<0.001\right)$ (Fig. 1).

The dynamics of expression of soluble forms of selected receptors was monitored as a new and prospective method of prediction of the results of therapy. The concentration of anti-inflammatory soluble scavenging receptor sCD-163 values were markedly higher

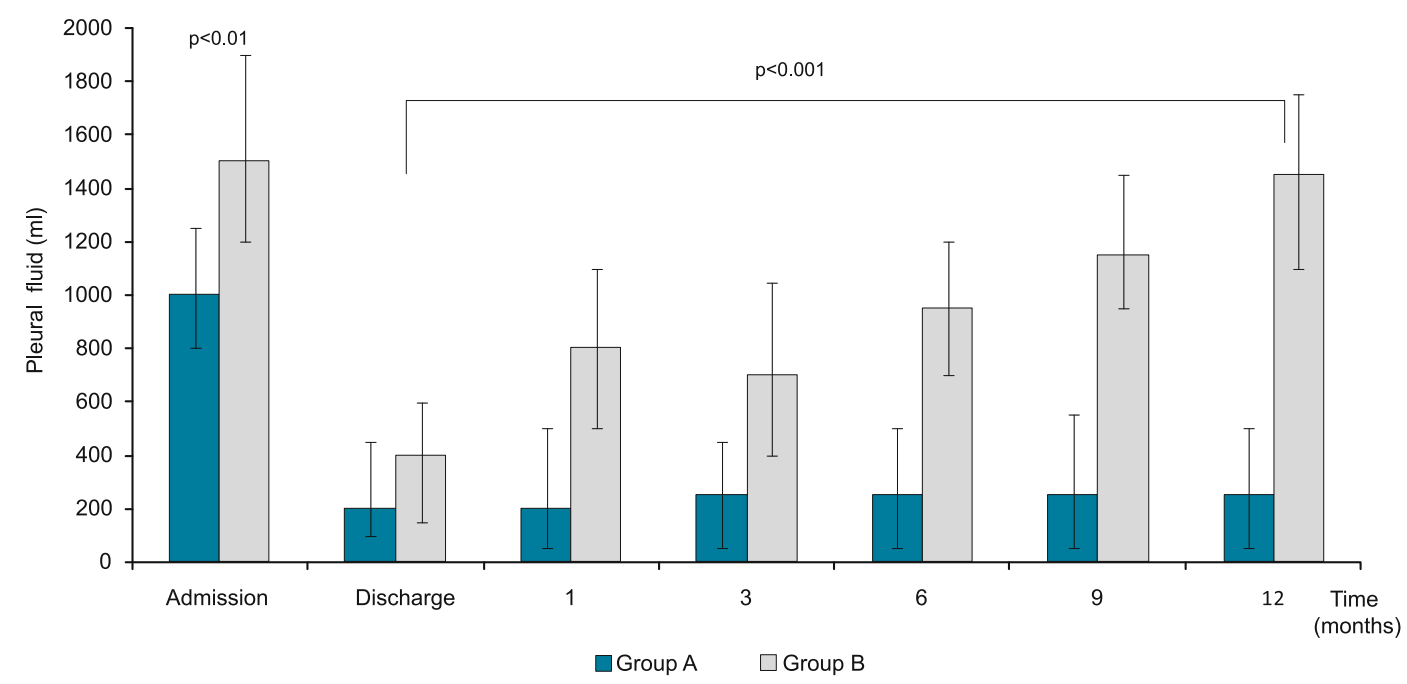

Fig. 1. The development of the volume of the pleural fluid in groups $A$ and $B . * * p<0.01,{ }^{* * *} p<0.001, A D-$ admission, $D-$ discharge. 


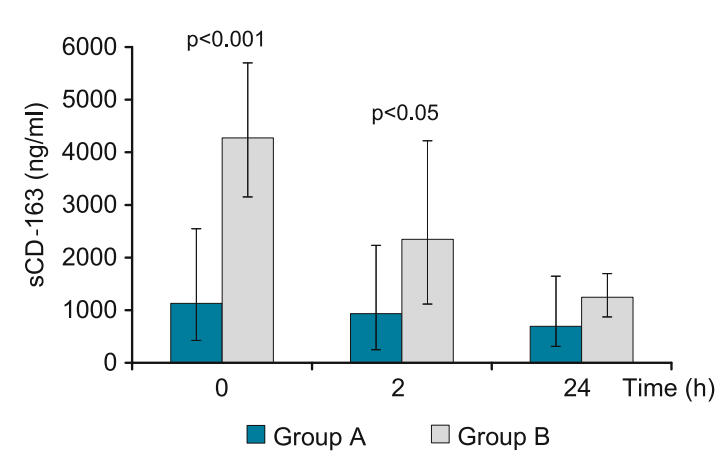

Fig. 2. Evolution of the values SCD-163 in the groups A and B. *** p $<0.001, *$ p $<0.05$.

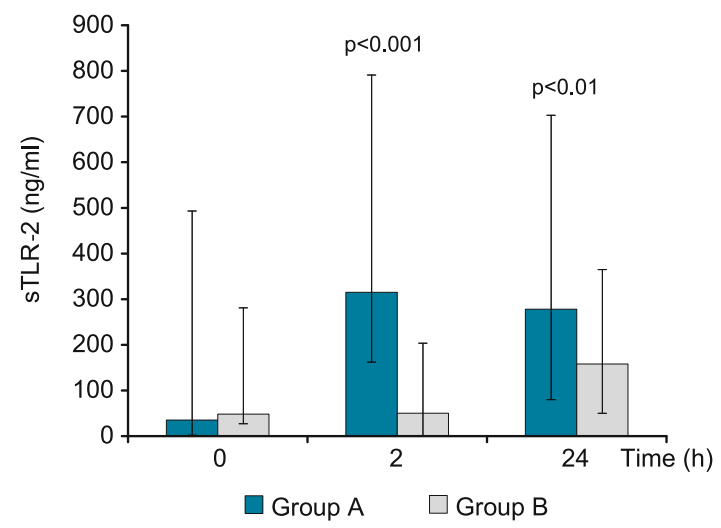

Fig. 3. Evolution of the values sTLR-2 in the groups A and B. *** p $<0.001$.

in Group B before talcage $\left(\mathrm{p}_{0}<0.001\right)$ and after two hours $\left(\mathrm{p}_{2}\right.$ $=0.028)$. No statistically significant difference was found after 24 hours $\left(\mathrm{p}_{24}=0.100\right)$ (Fig. 2).

The baseline values of anti-inflammatory parameter sTLR-2 were identical for both groups of patients $\left(\mathrm{p}_{0}=0.638\right)$. Dynamics of changes in the value concentration showed a significant increase in the group of patients with a successful effect (A) already two hours following talcage $\left(\mathrm{p}_{2}=0.002\right)$, and the increase continued also after 24 hours $\left(\mathrm{p}_{24}=0.016\right)$ (Fig. 3).

The initial values of the immune response enhancer, soluble forms of sTREM-1 receptor, were not different before talcage $\left(\mathrm{p}_{0}\right.$ $=0.146)$. After two hours, the significance of the increase in values in Group A was at $p_{2}<0.0064$ and after 24 hours the values were higher in Group A, but without statistical significance $\left(\mathrm{p}_{24}\right.$ $=0.0687$ ) (Fig. 4).

\section{Discussion}

Patients with performance status (PS) I-II are suitable for surgery according to the Karnofsky performance status at the interval between 50-70 \% and LE > 3 months (12). Each surgery causes severe surgical trauma (13). Coagulation and fibrinolytic blood system is activated, inflammatory response of the body is triggered (14). Controlled inflammatory response takes part in defence against infectious agents but it is necessary for healing the damaged tissue. The intensity of inflammatory response depends on the type of procedure and foreign material used. Therefore, it is stronger in surgeries using extracorporeal circulation compared to those not involving this procedure (15). In most of surgeries it is desirable to eliminate unsuitable inflammatory responses and to prevent organ impairments. In some surgeries, which are the subject of this work, the aim is to trigger the inflammatory cascade and to increase rather than suppress the effect by using a foreign substance. In our group the surgical burden was a constant value identical for both groups. Both groups underwent the same anaesthesia, surgical procedure and similar duration of surgery. To exclude other possibilities potentially affecting the inflammatory response the patients on corticotherapy or heparin were excluded from the study $(16,17)$. Most of the general inflammatory reactions in the body are non-specific. It is difficult to discriminate between the effect of operational stress and the effect of the foreign substance. Manifestations of changes in nonspecific inflammatory reactions such as increase in axillary temperature and leukocyte count, as well as changes in C-RP have been known for years. The first reaction in the general theory of inflammation was described by I.I.Mečnikov in 1903 (18). Although the changes in general body response can be objectivised and quantified they are unspecific and not suitable for prediction of therapeutic effect. Most of the maximal changes in values of generally known inflammation markers were found on the 3rd day (19). Following administration of talc the measurable differences in overall inflammatory response appeared between the groups after 36-48 hours (20).

High values of the anti-inflammatory receptor sCD-163 before talcage indicate that the patients were exposed to other external factors before therapy which, however, were not found in changes in the values of clinically commonly monitored markers (body temperature, CRP, leukocytes). A different reactivity of the observed pro-inflammatory receptors STLR-2 and STREM-1 between the groups indicated a different status of "readiness" or "depletion" of the immune system.

\section{Conclusion}

The fact that post-operative complications were not significant in both groups confirms the safety of VTS method and accuracy of the selected procedure in the selected group of patients. Pleurodesis is a result of the inflammatory reaction on both pleural membranes. A successful development of the reaction depends on the overall biological condition and metabolic activity of the body. Sufficient and long contact of both pleural membranes is important.

Examination with sCD-163 appears to be prospective using the ELISA method on the sample collected from pleural fluid before indication for surgery. High values may predict treatment failure. It should be considered whether the patient should be exposed to the risk of surgery. The intensity of reaction progression can be assessed after talcage by the development of sTLR-2 or sTREM-1 


\section{5-288}

values. In case of low reaction, talcage can be repeated at least in an aqueous solution by means of inserted thoracic drain. The cost of examination is 18 euros.

\section{References}

1. Agostini E. Mechanics of the pleural space. Physiolog Rev 1972; 52: $57-128$.

2. Agostini E, Zocchi L. Mechanical coupling and liquid exchanges in the pleural space. Clin Chest Med 1998; 19: 241-260.

3. Marel M, Zrustova M, Stastny B. The incidence of pleural effusion in a well-defined region. Epidemiologic study in central Bohemia. Chest 1993; 104: 1486-1489.

4. Bennett R, Maskell N. Management of malignit pleural effusions. Curr Opin Pulm Med 2005; 11: 296-300.

5. Bouros D, Froudarakis M, Siafakas NM. Pleurodesis: everything flows. Chest 2000; 118: 577-579.

6. de Campos JR, Vargas FS, Werebe E. Thoracoscopic Talc poudrage: a 15-year experience. Chest 2001; 119: 801-806.

7. Habal P, Mand'ák J, Štětina M. Monitorace efektivity chirurgické léčby maligních pleurálních výpotků. Klin Onkol 2010; 23 (2): 99-103.

8. Jankovicova K, Kondelkova K, Habal P, Krejsek J, Mandak J. TLR2 in Pleural Fluid Is Modulated by Talc Particles during Pleurodesis. Clinical and Developmental Immunology 01/2012; 2012: 158287. DOI: 10.1155/2012/158287.

9. Krejsek J, Kuneš P, Andrýs C. Přirozená imunita, receptory pro exogenní a endogenní nebezpečné vzory $\mathrm{v}$ imunopatogenezi aterosklerózy. Čas Lék Čes 2005; 144 (2): 785-789.113.
10. Onofre G, Koláčková M, Jankovičová K. Scavenger receptor cd163 and its biological functions Acta medica (Hradec Králové) 2009; 52 (2): $57-61$.

11. Roldan NG. TREM-1 on myeloid cells and histocompatibility complex molecules in sepsis and major abdominal surgery. World Gastroenterol $2005 ; 7473-7479$.

12. Schag CC, Heinrich RL, Ganz PA. Karnofsky performance status revisited: Reliability, validity, and guidelines. J Clin Oncology1984; 2: 187-190.

13. de Longu G, Moretti S, Antonucci A. Apoptosis and surgical trauma. Arch Surg 2000; 135: 1141-1147.

14. Hornick P, Georgie A. Blood contact activation: pathophysiological effects and therapeutic approches. Perfusion 1996; 11: 3-19.

15. Paparella D, Yau TM, Young E. Cardiopulmonary bypass induced infammation: patophysiology and treatment. An update. Eur J Cardiothorac Surg 2002; 21: 232-244.

16. Rodriguez-Panadero F, Segado A, Martin J. Activation of systemic coagulation in talc poudrage can be partially controlled with prophylactic heparin. Am J Respir Crit Care Med 1996; 152: 458.

17. Xie C, Teixeira LR, Wu W, Chang DS. The effect of corticosteroids on pleurodesis induced by doxycycline in rabbits. Chest 2002; 121:216-219.

18. Lokaj J, John C. Ilja Iljič Mečnikov a Paul Ehrlich: laureáti Nobelovy ceny v r. 1908 za práce o imunitě. Epidemiol Mikrobiol Imunol 2008; 57 (4): 119-124.

19. Shimaoka M, Hosothubo K, Sugimoto M. The influence of surgical stress on t cells? Enhancement of early phase lymphocyte activation. Anesth Anal 1998; 87: 1431-1435.

20. Habal P, Mand'ák J, Štětina M. Monitorace efektivity chirurgické léčby maligních pleurálních výpotků. Klin Onkol 2010; 23 (2): 99-103.

Received March 20, 2014. Accepted January 20, 2015. 